\title{
ВПЛИВ ГЛОБАЛІЗАЦЇ̈ НА ПРОЦЕС НАВЧАННЯ ІНОЗЕМНИХ МОВ У ШКОЛІ: ДОСВІД СПОЛУЧЕНОГО КОРОЛІВСТВА ВЕЛИКОЇ БРИТАНІЇ ТА ПІВНІЧНОЇ ІРЛАНДІЇ
}

Гриненко Д. В. Вплив глобалізації на процес навчання іноземних мов у школі: досвід Сполученого Королівства Великої Британії та Північної Ірландії.

У статті розглядаються основні тенденції розвитку та dдосконалення процесу навчання іноземних мов у Сполученому Королівстві Великої Британії та Північної Ірландії в період глобалізації. Продемонстрований позитивний та негативний вплив суспільних змін на ефективність іншомовної освіти.

Ключові слова: глобалізація, британська іншомовна освіта, середні загальноосвітні заклади.

Гриненко Д. В. Влияние глобализации на процесс обучения иностранных языков в школе: опыт Соединенного Королевства Великобритании и Северной Ирландии.

В статье рассматриваются основные тенденции развития и усовершенствования процесса обучения иностранным языкам в Соединенном Королевстве Великобритании и Северной Ирландии в период глобализации. Продемонстрировано позитивное и негативное влияние общественных изменений на эффективность иноязычного образования.

Ключевые слова: глобализация, британское иноязычное образование, средние общеобразовательные заведения.

Grynenko D. V. The impact of globalization on the process of teaching foreign languages in the secondary schools of the United Kingdom of Great Britain and Northern Ireland.

The article covers the main tendencies of the development and the improvement of the process of teaching foreign languages in the United Kingdom of Great Britain and Northern Ireland in the period of globalization. The positive and the negative influence of the social changes on the effectiveness of the foreign languages education.

Key words: globalization, British foreign languages education, secondary schools.

Глобалізація як явище, що полягало в очевидній культурній, економічній та політичній інтеграції, мало неймовірний вплив на різноманітні сфери життя людства у другій половині XX століття. В умовах постійного суспільного розвитку та зближення народів світу виникає потреба в модернізації освіти в цілому та іншомовної освіти зокрема, котра, як відомо, за будь-яких обставин повинна відповідати сучасним вимогам. Країни Європи, у тому числі Великобританія, виявилися одними 3 перших, котрі зрозуміли нагальність вирішення питання вдосконалення іншомовної освіти задля прискорення процесів глобалізації на території власних держав. Водночас у випадку Великобританії вплив цього явища на процес навчання іноземних мов у середніх загальноосвітніх закладах став, вочевидь, неоднозначним: 3 одного боку, періоду початку глобалізації була притаманна сформованість високого рівня англомовної компетентності випускників школи, у той час як, 3 іншого боку, вивчення іноземних мов виявилося другорядним через невмотивованість учнів у процесі їх навчання, що постало величезною загрозою для розвитку іншомовної освіти. Шляхи ефективного розв'язання цієї проблеми, а також фактори, що 
уможливили цей процес, представляють значний інтерес для сучасної науки.

Питання глобалізації суспільства як важливого явища сучасного світового розвитку було досліджене в працях таких українських та зарубіжних науковців, як Д. Блок, О. Волович, Н. Гастон, А. Сбруєва, С. Сидоренко, Дж. Тілл, М. Трофименко. Вплив глобалізації на освіту вивчали І. Богданова, К. Монкман, О. Павліченко, Л. Парментер, Н. Стромквіст. Особливості розвитку іншомовної освіти у Великобританії в умовах світової глобалізації стало предметом дослідження Р. Гарріса, Д. Джоунса, В. Едвардса, К. Леунга, Б. Рамптона та інших. Однак вищезгадані дослідження не можуть представити цілісну картину розвитку та вдосконалення процесу навчання іноземних мов у середніх загальноосвітніх закладах Сполученого Королівства Великої Британії та Північної Ірландії, а тому це питання потребує подальших наукових пошуків.

Мета статmі полягає у виокремленні та презентації основних особливостей навчання іноземних мов у Великобританії в зазначений період, а також визначенні позитивного та негативного впливу глобалізації на процес формування іншомовної компетентності школярів. У процесі дослідження був здійснений аналіз наукових джерел, що стосуються його теми, зокрема психолого-педагогічної літератури, а також офіційних документів, у тому числі навчальних програм та стандартів. Крім того, був застосований порівняльно-зіставний метод дослідження.

Одним з ключових етапів розвитку іншомовної освіти Сполученого Королівства Великобританії та Північної Ірландії став період початку глобалізації, процесу, який триває і дотепер. Сучасні науковці по-різному визначають це поняття. Так, на думку Н. Стромквіст, воно «охоплює величезну кількість неймовірних змін у всіх сферах соціального життя, у тому числі у сфері економіки, технології та культури» [9, с. 1]. Дж. Гібсон-Грахам визначає глобалізацію як «сукупність процесів, що стимулюються зростаючою кількістю глобальних телекомунікаційних систем та призводять до швидкої світової інтеграції до єдиного економічного простору за допомогою зростання масштабів світової торгівлі, інтернаціоналізації виробництва, фінансових ринків, а також споживчої культури» $[9$, с. 1]. Однак, незважаючи на різноманітність визначень вищезгаданого поняття, усі дослідники погоджуються на тому, що глобалізація стала основоположним чинником у підтримці та розвиткові міжнаціональних зв'язків, а тому особливо актуалізувала потребу у вивченні іноземних мов як засобу міжкультурної комунікації. У цей час починається новий етап у розвиткові світової іншомовної освіти. У Великобританії цей процес варто поділити на дві стадії:

- перша стадія (кінець XX-початок XXI століття);

- друга стадія (початок XXI століття - сучасність).

Задля спрощення комунікації між представниками різних національностей наприкінці XX століття виникає потреба у виокремленні єдиної, універсальної мови. Такою мовою стає англійська, витісняючи при цьому французьку, німецьку та російську та відіграючи роль мови політики та міжнародних відносин. Крім того, англійська починає визначатися як офіційна мова провідних авіаліній, активно застосовується під час теле- та радіотрансляцій. Кожен освічений європеєць вивчає іiі як другу, третю чи четверту іноземну та використовує набуті знання на практиці під час ділових чи туристичних поїздок [10, с. 55]. Подібні зміни в перерозподілі функцій англійської в житті суспільства викликає популяризацію цієї мови у всьому світі та певний занепад іншомовної освіти в англомовних країнах, зокрема і у Великобританії. Так, незважаючи на те, що у своїй іншомовній політиці Рада Європи зробила особливий наголос на важливості міжкультурної комунікації та збереження мовного 
різноманіття, а також розробки Загальноєвропейських критеріїв визначення рівня володіння іноземною мовою [2, с. 80], особливо нагальною для вирішення залишається проблема учнівської мотивації, котра значною мірою сповільнює процес розвитку іншомовної освіти у Великобританії.

Як відомо, мотивація вивчення того чи того предмета напряму залежить як від зовнішніх, так і від внутрішніх чинників. Основний зовнішній чинник полягає в успішному складанні іспитів, у той час як внутрішній охоплює можливість досягнення власних цілей за допомогою набутих знань [5, с. 121]. У випадку британських шкіл учнівська мотивація базувалася лише на зовнішньому компонентові, котрий був недостатнім, у той час як внутрішній, як правило, був відсутнім. Погіршувала цю досить складну ситуацію і професійна орієнтація шкільної освіти у Великобританії, оскільки більшість школярів не вважала за необхідне пов'язувати подальшу діяльність з хоча би однією іноземною мовою. Усі вищезгадані чинники спричинили не лише низький рівень успішності дітей, а й скорочення кількості школярів, котрі бажали вивчати певну мову. Згідно із статистичними даними в період з 2000 по 2007 рік число бажаючих навчатися французькій мові зменшилося 3 54,0 до 28,7 \%, а німецькій - 322,0 до 11,5 \%. Єдиною мовою, яка не втратила своєї популярності стала іспанська, інтерес до якої зріс на 2,2 \% [8, с. 3]. Фахівці пояснюють подібні тенденції тим, що, по-перше, Іспанія продовжує «вважатися досить привабливим туристичним місцем, а, по-друге, 86 \% людей, які є іспаномовними, живуть у Південній Америці, а тому іспанська не розглядається як європейська мова» [1, с. 78].

Водночас слід відзначити і деякий позитивний вплив процесів глобалізації на британську іншомовну освіту. Так розширення кордонів виробництва, а також створення таких світових брендів, як Майкрософт, Найк, МакДональдс та ін. зумовили зростання масштабів міграції. Причиною цьому стала поява все більшої кількості носіїв таких мов, як французька, арабська, іспанська, грецька, португальська, російська, турецька, мови гінді та урду, тощо [6, с. 27]. Отже, у Сполученому Королівстві Великої Британії та Північної Ірландії починають 3'являтися засоби масової інформації китайською, польською, італійською та арабською мовами. Крім того, національні меншини значно впливають на релігійне та культурне життя країни, зокрема на розвиток мистецтва. Подібні тенденції не лише актуалізували вивчення англійської мови як іноземної представниками національних меншин, а й змогли максимально підтримати процес вивчення інших іноземних мов британськими школярами. У цей час актуальними залишаються не лише гельська, ірландська, шотландська та уельська мови, а й мови етнічних меншин, котрі з'явилися зовсім недавно на території Великобританії.

Окрім того, задля підтримки іншомовної освіти в середніх загальноосвітніх закладах Великобританії Рада Європи, а також британський уряд вжили низку заходів. Так, зі свого боку, Рада Європи зобов'язалася максимально сприяти співпраці між освітніми закладами Великобританії та інших країн, створити спільні для всіх європейських країн критерії оцінки іншомовних знань, підтримувати учнів, учителів, розробників програм та керівників освітніх закладів 3 метою координації їх роботи [4, c. 5-6].

У свою чергу, уряд Сполученого Королівства Великої Британії та Північної Ірландії виокремив нові шляхи поліпшення ситуації у сфері навчання іноземних мов, a саме:

- «надання можливості отримання дипломів 3 іноземних мов як альтернатива документа про середню освіту (GCSE)» [1, с. 79]; 
- переорієнтація цілей навчання;

- удосконалення навчальних матеріалів;

- збільшення тривалості процесу навчання іноземних мов;

- індивідуалізація навчання [3, с. 21];

- сприяння розв'язанню проблеми кваліфікації вчителів.

Окрім того, Департамент освіти Сполученого Королівства Великої Британії та Північної Ірландії зробив особливий наголос на забезпеченні практичності знань, набутих школярами у процесі вивчення іноземної мови. Так, в офіційних критеріях до змісту предмета «Іноземна мова» у школі зазначається, що іншомовна освіта повинна «заохочувати учнів до отримання задоволення від навчального процесу, ... забезпечуючи їх змістовною навчальною програмою, що задовольняє потреби школярів. Учням слід усвідомлювати корисність набутих лінгвістичних знань та навичок у процесі їх особистої реалізації в мультилінгвальному глобалізованому суспільстві, а також слугувати їм важливою основою для подальшого навчання та практичного використання» [7, с. 3].

Важливим поштовхом до вдосконалення іншомовної освіти у Великобританії стали й деякі зовнішні чинники, а саме: досить високий рівень іншомовних знань батьків, їх закордонні поїздки, а також необхідність практичного застосування дітьми іноземної мови вже у шкільному віці [3, с. 21].

Отже, починається новий етап у розвитку британської іншомовної освіти, зумовлений зростанням вмотивованості школярів. Подібні зміни сприяли й підвищенню рівня навчальних досягнень. Згідно 3 дослідженнями 2011 року усвідомлення учнями корисності навчального процесу мало значний позитивний вплив на одразу три види навичок (читання, аудіювання та письмо) [3, с. 20]. Однак, незважаючи на позитивні зрушення в навчанні іноземних мов у середніх загальноосвітніх закладах Великобританії, через досить тривалий період слабкого розвитку британської іншомовної освіти та недостатньої уваги, що приділялася їй, на міжнародному рівні ця країна демонструє одні з найнижчих результатів. Так, загальна оцінка іншомовної компетентності 3 п'яти найбільш популярних для вивчення мов серед країн Європи виявилася найнижчою серед учнів Великобританії, Польщі та Швеції. Тим не менш, рівень знань 3 французької мови британських та португальських школярів виявився вищим, ніж іспанських учнів. Досить низькі результати продемонстрували британські діти 3 німецької мови, виявившись на одному рівні з польськими школярами.

Отже, процеси глобалізації мали досить неоднозначний вплив на розвиток британської іншомовної освіти. 3 одного боку, вони спричинили зосередження максимальної уваги на мови національних меншин, 3 іншого боку, призвели до невмотивованості школярів, а значить, зниження рівня учнівських навчальних досягнень. Ураховуючи досить складну ситуацію, що складалася у процесі формування іншомовної компетентності випускників, були вжиті ефективні заходи задля розв'язання наявних проблем. Незважаючи на те, що іншомовна освіта Великобританії не може вважатися ідеальною, позитивний досвід цієї країни у сфері вдосконалення процесу навчання іноземних мов може слугувати яскравим прикладом для наслідування іншими країнами, які лише знаходяться на початку цього шляху.

\section{Література}

1. Балацька Н. Тенденції розвитку освіти у Великій Британії та США (на матеріалі англомовної преси 2006-2007 років) // Рід. шк. - 2008. - № 5. - С. 78-80. 2. Bärenfänger O. Language Educational Policy and Language Learning Quality 
Management / Olaf Bärenfänger, Erwin Tschirnen // Foreign Language Annals. - 2008. № 1. - P. 79-99. 3. Burge Bethan. European Survey on Language Competences: Language Proficiency in England / Bethan Burge, Ager Robert, Cook Rose, Cunningham Rachel, and others. - Department of Education, 2013. - 246 p. 4. Council of Europe. Relating Language Examinations in the Common European Framework of References for Languages: Learning, Teaching, Assessment (CEF). - 2003. - Strasbourg, France. 5. Dörnyei Zoltn. Motivation in Second and Foreign Language Learning / Zolt'n Dörnyei // Language Teaching. - 1998. № 3. - P. 117-135. 6. Edwards Viv. Globalization and Multilingualism: the Case of the UK / Viv Edwards // Intercultural Communication Studies. - 2011. - № 1. - P. 27-35. 7. GCSE Subject Criteria for Modern Foreign Languages. - Ofqual. - September, 2011 8. Paton Graeme. Fewer than Half of Pupils Take a Language GC5 / Graeme Paton // The Daily Telegraph. - 2007. - № 7. - P. 3. 9. Stromquist Nelly P. Globalization and Education: Integration and Contestation across Cultures / Nelly P. Stromquist, Monkman Karen. - Plymouth: R\&L Education, 2014. - 362 p. 10. Wiarda Howard J. Globalization: Universal Trends, Regional Implications / Howard J. Wiarda. - Lebanon : North-eastern University Press, 2007. - 286 p.

УДК 37.014 .5

Ганна Давиденко

\section{РЕТРОСПЕКТИВНИЙ АНАЛІЗ УПРОВАДЖЕННЯ ІНКЛЮЗИВНОЇ ОСВІТИ В НІМЕЧЧИНІ}

Давиденко Г. В. Ретроспективний аналіз упровадження інклюзивної освіти в Німеччині.

Статтю присвячено дослідженню питання про впровадження інклюзивної освіти у Німеччині. У статті розглянуто історичні віхи становлення інклюзивної освіти у Німеччині, окреслено законодавче підгрунтя та сучасний стан упровадження інклюзивного навчання для людей з інвалідністю.

Ключові слова: інклюзія, спеціальна освіта, інтеграція, інклюзивне навчання, інклюзивна освіта.

Давыденко А. В. Ретроспективный анализ внедрения инклюзивного образования в Германии.

Статья посвящена исследованию вопроса о внедрении инклюзивного образования в Германии. В статье рассмотрены исторические вехи становления инклюзивного образования в Германии, очерчена законодательная почва и современное состояние внедрения инклюзивного обучения для людей с инвалидностью.

Ключевые слова: инклюзия, специальное образование, интеграция, инклюзивное обучение, инклюзивное образование.

Davydenko H. V. The Retrospective Analysis of Introduction of Inclusive Education in Germany.

The article deals with the process of implementation of inclusive education in Germany. The historical landmarks of inclusive education formation in Germany are studied. The legislative background and modern state of inclusive education implementation for people with disability are outlined.

Key words: inclusion, special education, integration, inclusive studies, inclusive education. 